\title{
GROUND AND IN-FLIGH TESTING OF COOLING EFFICIENCY OF TURBOPROP ENGINE COMPARTMENT
}

\author{
Marek Idzikowski, Wojciech Miksa \\ Center of New Technologies, Institute of Aviation, \\ al. Krakowska 110/114, 02-256 Warsaw, Poland \\ marek.idzikowski@ilot.edu.pl,wojciech.miksa@ilot.edu.pl
}

\section{Abstract}

This article presents selected results of I-31T propulsion tests, obtained in the framework of EU project ESPOSA (Efficient Systems and Propulsion for Small Aircraft). I-31T aircraft, as a testbed, was fitted with $180 \mathrm{~kW}$ turboprop engine TP100. The scope of the work include results of ground and in-flight tests of engine compartment cooling suitability. The purpose of the cooling tests was to prove that temperatures of the propulsion components are within limits set by the engine manufacturer for the engine type in the most disadvantageous conditions on the ground and in flight up to aircraft maximum altitude, maximum ambient temperature and after standard engine shutdown. Engine oil cooling is beyond the scope of this work.

Keywords: light aircraft, in-flight tests, turboprop engine installation, turboprop engine integration in airframe, engine compartment cooling.

\section{INTRODUCTION}

I-31T is a light (maximum take-off mass $1150 \mathrm{~kg}$ ), four seat, all-composite low wing monoplane with retracted tricycle undercarriage. Aircraft is powered by a prototype TP100 turboprop engine, manufactured by Czech firm První Brněnská Strojírna Velká Bíteš, a.s. (PBS). Maximum takeoff shaft power is $180 \mathrm{~kW}$ at 2158 rotations per minute (r.p.m.), maximum continuous power is $160 \mathrm{~kW}$ and cruise power is $140 \mathrm{~kW}$. TP100 is air cooled and equipped with Electronic Control Unit (ECU). The engine drives 1,80 meter, German 5-blade, variable pitch, constant speed, propeller type MT-Propeller MTV-25-1-D-C-F/CFL180-05. The propeller can be feathered, but there is no reverse pitch.

The I-31T flight test programme included propulsion tests verifying fulfillment of European Aviation Space Agency (EASA) Certification Specifications for Normal Category Aeroplanes CS-23 Amendment 3 [1]. Center of New Technologies at Institute of Aviation elaborated the test programme, supervised and carried out the tests. 
This article focuses on the tests to validate the design of engine compartment cooling system. The remainder of the article is organized as follows: Section 2 contains overview of the engine installation, Section 3 provides the limiting temperatures of the engine components set by the manufacturer, Section 4 presents test procedures and results, while Section 5 concludes the article with discussion of the tesz results.

\section{TP100 TURBOPROP ENGINE INSTALLATION}

Engine installation design must address the need to cool the engine compartment. Cooling design affects propulsion system economic efficiency, environmental impact and sustainability [2, 3], though its improvement potential is limited [2]. Sufficient amount of airflow is required to reach engine hull, its aggregates and accessories to keep the temperatures below the acceptable limits for continuous operation. It is typically $100{ }^{\circ} \mathrm{C}$ or $70^{\circ} \mathrm{C}$ for electronic devices. Fuel and oil installation components require cooling as well, due to exposure to heat emitted by the engine hull. Engine compartment cowling parts are also vulnerable to high temperature, as they are made of composite.

Aviation Structures and Design Department at Institute of Aviation developed the whole engine installation design, while Aerodynamic Department did the necessary numerical analyses of air circulation in the engine compartment $[4,5]$. Air flow through the duct was significantly complicated due to complex, three dimensional shape of the designed firewalls and three vents in the upper cowl.

Figure 1. shows engine installation design. Nose air intake comprises the main intake and two symmetrical intakes at both sides. Purpose of the main air intake is to provide air to the engine compressor. The left side intake provide air for the engine oil cooler and to cool the hull of engine gas generator. The right side intake provides air to cool the radiator of electrical generator convector (the generator is source of power for aircraft electrical system) and to cool the engine hull as well. Additionally, this intake supplies air for the heater, that can be used after increasing the flowing air temperature, to warm up the cockpit.

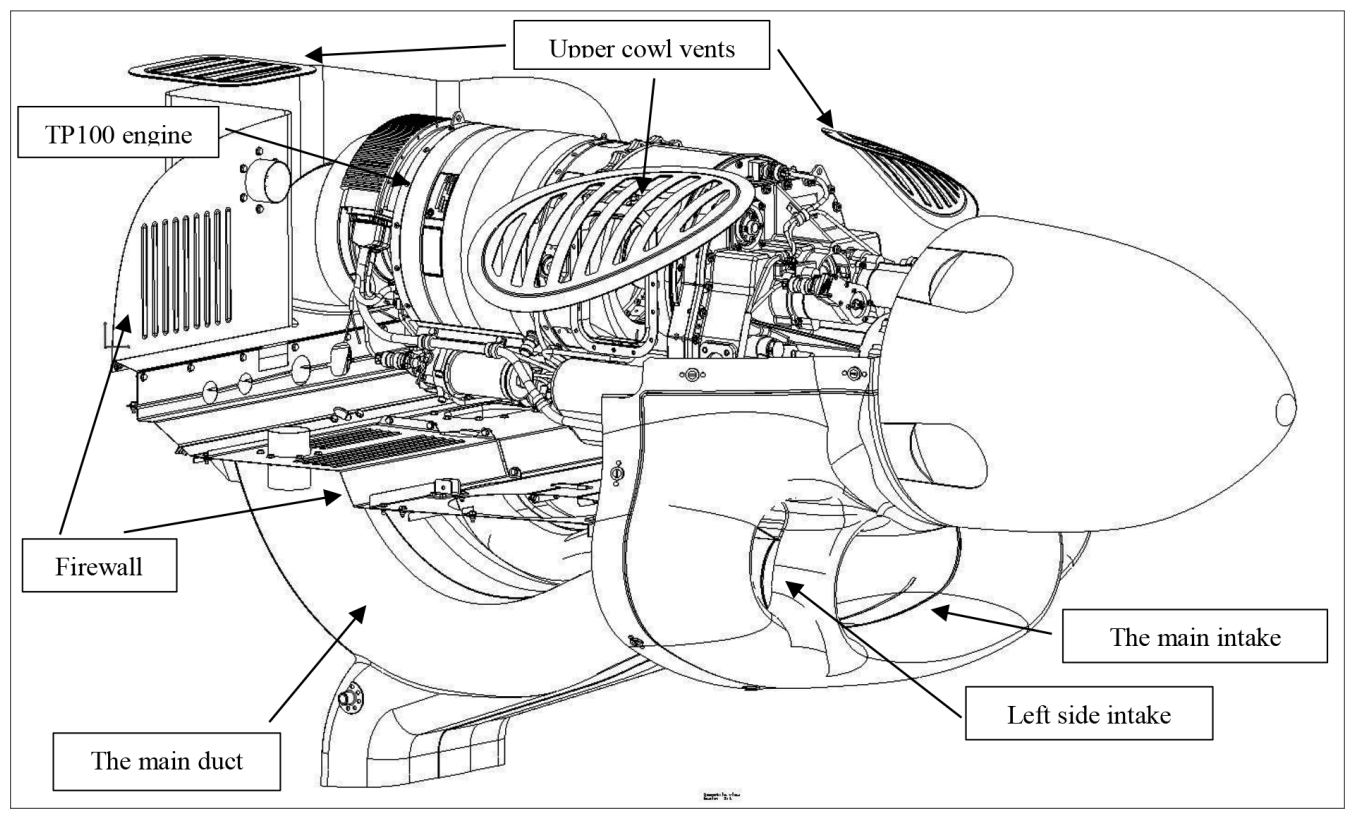

Fig. 1. Propulsion with visible firewall, cooling system and vents in the upper cowl 


\section{TEMPERATURE LIMITS FOR ENGINE COMPONENTS}

Figures 2, 3 show temperature limits set by the engine manufacturer for individual engine components. Figure 4 show, also set by the manufacturer, maximum allowable temperatures for the engine hull and oil tank walls.

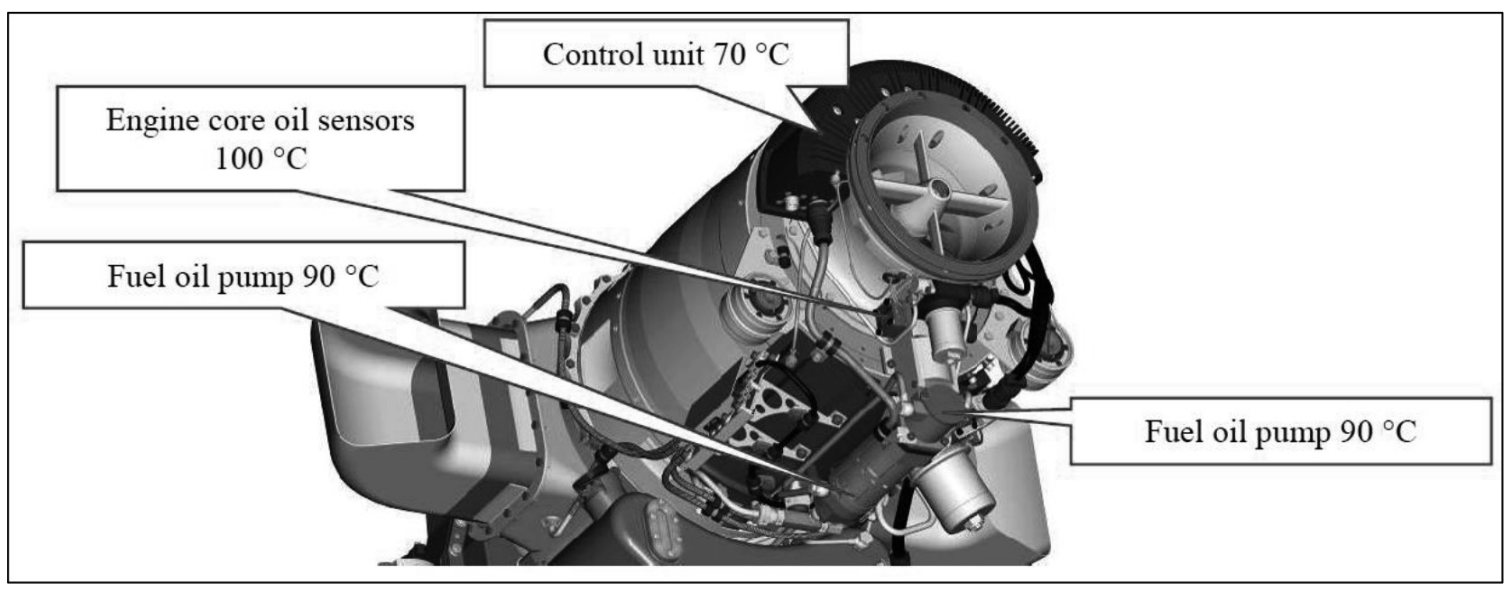

Fig. 2. Limit temperature allowed by the manufacturer in the vicinity of Engine Control Unit (ECU), engine core oil sensors two fuel-oil pump zones

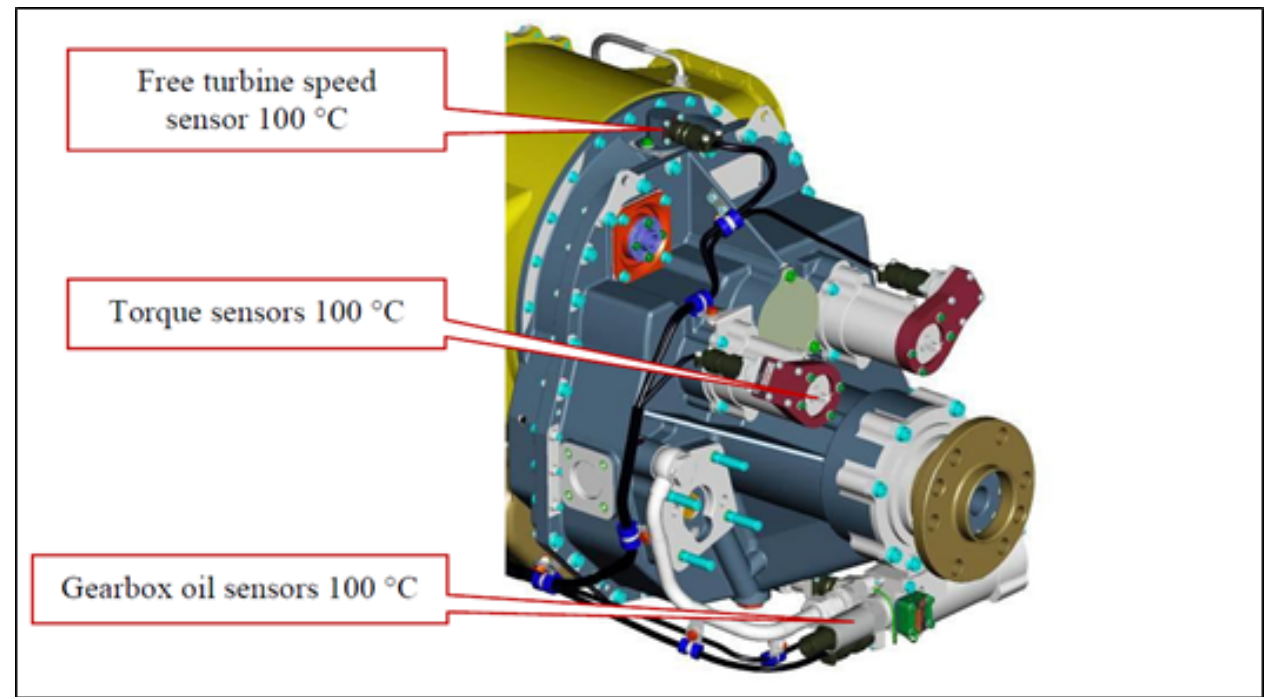

Fig. 3. Limit temperatures permitted in the vicinity of: free turbine speed sensor, torque sensors and gearbox oil sensors 


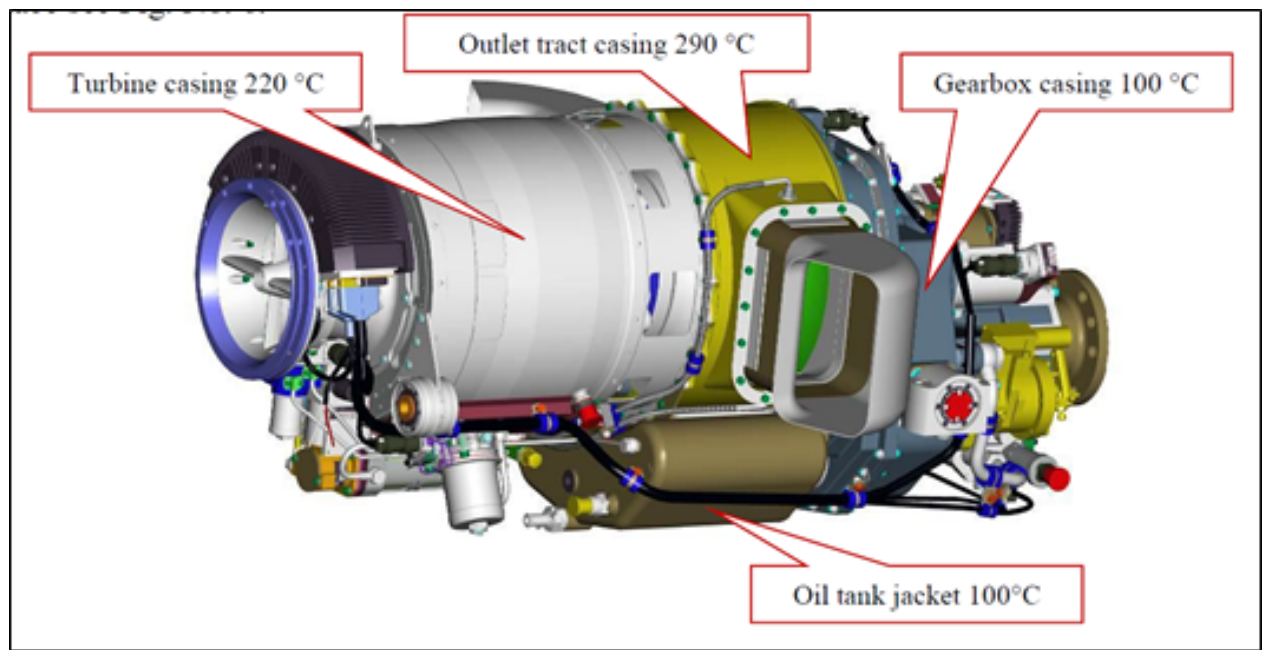

Fig. 4. Engine hull and oil tank allowable temperatures

\section{TEST EQUIPMENT USED}

During the tests, I-31T was equipped with portable, on-board system that recorded and visualized engine compartment temperatures. The system comprise four temperature sensors, which locations were determined by numeric simulations [4] and ground tests. Three of the sensors barely touched internal area of the engine cowling, which allowed to monitor temperatures in critical areas of the cowling. A crew member (the observer) could monitor the temperatures from all the four sensors in real time on a tablet, in addition to analyzing the recorded values after a flight. Ability to monitor the temperatures in real time allowed to avoid the flight conditions that were too close to the allowed limits. Locations of temperature sensors were as follows:

$\mathrm{T} 1$ - temperature around ECU area,

$\mathrm{T} 2$ - temperature of internal area of the upper engine cowl over gas generator,

T3 - temperature of internal area of the upper engine cowl over exhaust gases path,

T4 - temperature of internal area of the upper engine cowl over left exhaust collector.

Additionally, temperature indicators (THERMAX) permanently recorded the highest temperature. They were stuck to numerous locations in the engine compartment: composite engine cowling, engine aggregates and accessories, oil tank and engine mount tubes. Table 1 shows accuracy of temperature indicators and sensors used in the tests. 


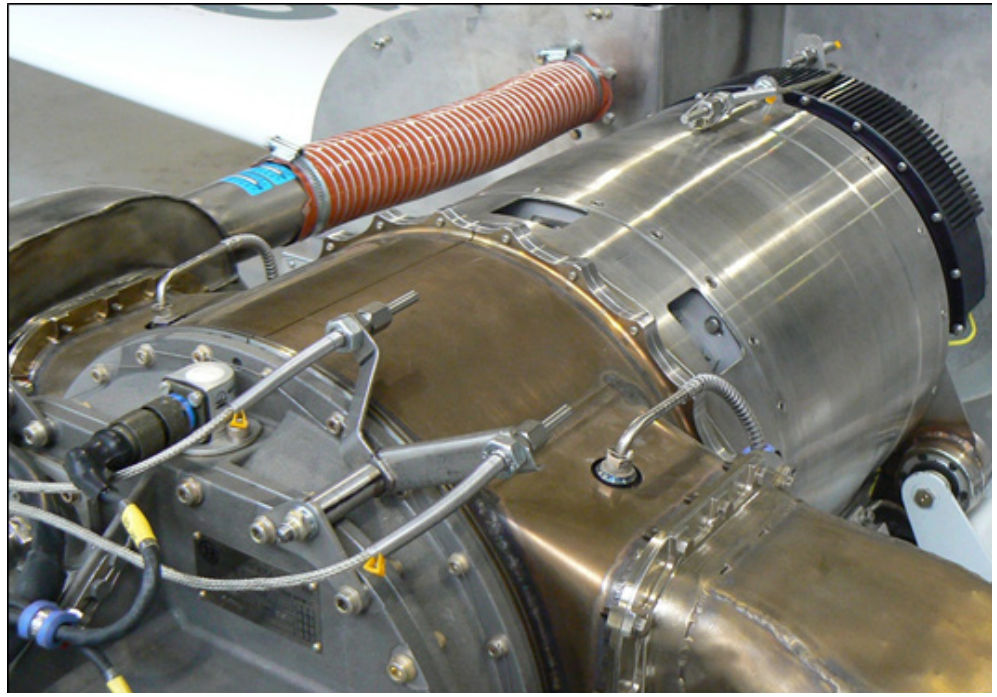

Fig. 5 . T1 $\div$ T4 temperature sensors locations on the engine structure

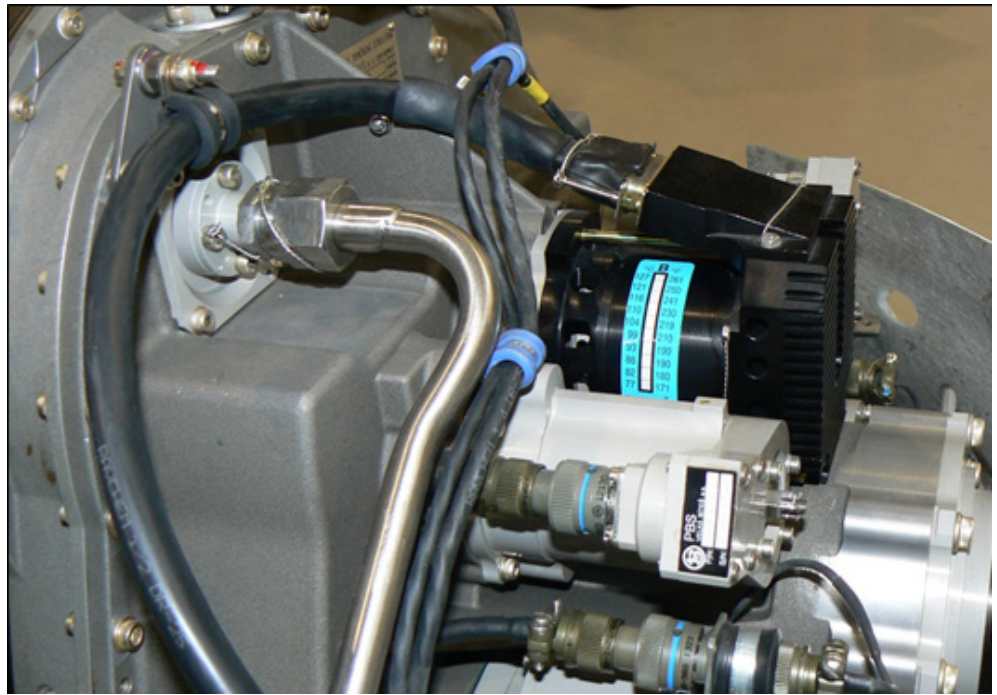

Fig. 6. THERMAX ${ }^{\circ}$ strip temperature indicator stuck to $3 \mathrm{~kW}$ electric generator

Table 1. Accuracy of the on-board recroding system used in the tests

\begin{tabular}{|l|l|l|}
\hline & Tolerance & Response Time \\
\hline Temperature sensors $\mathrm{T} 1 \div \mathrm{T} 4$ measurement paths & $\pm 1.5^{\circ} \mathrm{C}$ & 10 to 15 seconds \\
\hline Temperature indicators THERMAX & $\begin{array}{l}29 \text { to } 99{ }^{\circ} \mathrm{C}= \pm 1{ }^{\circ} \mathrm{C} \\
100 \text { to } 154^{\circ} \mathrm{C}= \pm 1.5^{\circ} \mathrm{C}\end{array}$ & 2 to 5 seconds \\
\hline
\end{tabular}

The pilot controlled the engine power using PBS TL-6724 INTEGRA monitoring system, that showed, inter alia, digital and analogue visualization of current oil temperature. 


\section{TEST PROCEDURES AND RESULTS}

\subsection{Evaluation of engine compartment cooling during power reduction on the ground and right after shutdown}

Several long (over 1 hour each) ground tests with various power settings were done in order to measure temperature values in the engine compartment with the engine running. The tests confirmed that cooling by the propeller backwash is sufficient as the recorded $\mathrm{T} 1 \div \mathrm{T} 4$ values exceeded current ambient temperatures by no more than $25^{\circ} \mathrm{C}$ at most.

On completion of TP100 shutdown, ECU automatically initiates after-cooling. During this process (automatic function), gas generator is rotated by the electric starter powered by onboard battery, while the propeller is not moving. It takes a few minutes and is automatically concluded, when exhaust gases temperature falls below the set limit. $\mathrm{T} 1 \div \mathrm{T} 4$ values gradient abruptly rise. This rise accelerates even more when the cooling is stopping. The maximum recorded values are: $\mathrm{T} 1=63{ }^{\circ} \mathrm{C}, \mathrm{T} 2=30{ }^{\circ} \mathrm{C}$, $\mathrm{T} 3=108{ }^{\circ} \mathrm{C}, \mathrm{T} 4=131{ }^{\circ} \mathrm{C}$ (for ambient temperature $30^{\circ} \mathrm{C}$ ).

All the temperatures recorded by the strip indicators on the engine composite cowling, aggregates, accessories, oil tank and mount tubes were below their limits.

\subsection{Evaluation of engine compartment cooling during flight.}

The test were carried out in accordance with „Flight Test Guide for Certification of CS-23 Aeroplanes", part of CS-23 [1]. Engine lubrication system was filled with minimum permitted amount of oil. Temperature was considered stable it did not changed faster than $2{ }^{\circ} \mathrm{C}$ per minute. The flight took place in hot arid day with temperature $31^{\circ} \mathrm{C}$ (in the shade) at altitude $1,5 \mathrm{~m}$, so that temperature drop with altitude would be close to values defined in the International Standard Atmosphere (ISA).

Test program and proceedings were as follows:

1. Standard engine start,

2. Taxiing approximately $2000 \mathrm{~m}$,

3. Waiting before taking-off, at least 20 minutes after stabilization of measured temperatures of oil and in the engine compartment,

4. Lift off in take-off configuration, followed by 5 minute climb in clean configuration, at take-off power and speed $20 \%$ greater than stall speed (for clean configuration),

5. Continuing of climb with Maximum Continuous Power (MCP) until achieving maximum operational altitude, at speed $20 \%$ greater than stall speed,

6. Cruise at maximum operational altitude, with MCP until the measured oil and engine compartment temperatures stabilize,

7. Descent with normal operational speed $\left(\mathrm{V}_{\mathrm{NO}}\right)$ until aerodrome traffic pattern altitude is achieved and loitering until the measured oil and engine compartment temperatures stabilize,

8. Standard approach,

9. Standard go-around at low altitude, in accordance with Aircraft Flight Manual (AFM),

10. Final approach and landing,

11. Several minute long taxiing to a parking place,

12. Engine shutdown while monitoring the measured temperatures after the sequence is completed, until extreme values are achieved. 
Fig 7. shows $\mathrm{T} 1 \div \mathrm{T} 4$ temperature values during the test flight. Only $\mathrm{T} 4$ reached almost $70{ }^{\circ} \mathrm{C}$, while the remaining temperatures never exceeded $50^{\circ} \mathrm{C}$. T4 and T3 values quickly increased straightaway after the engine shutdown.

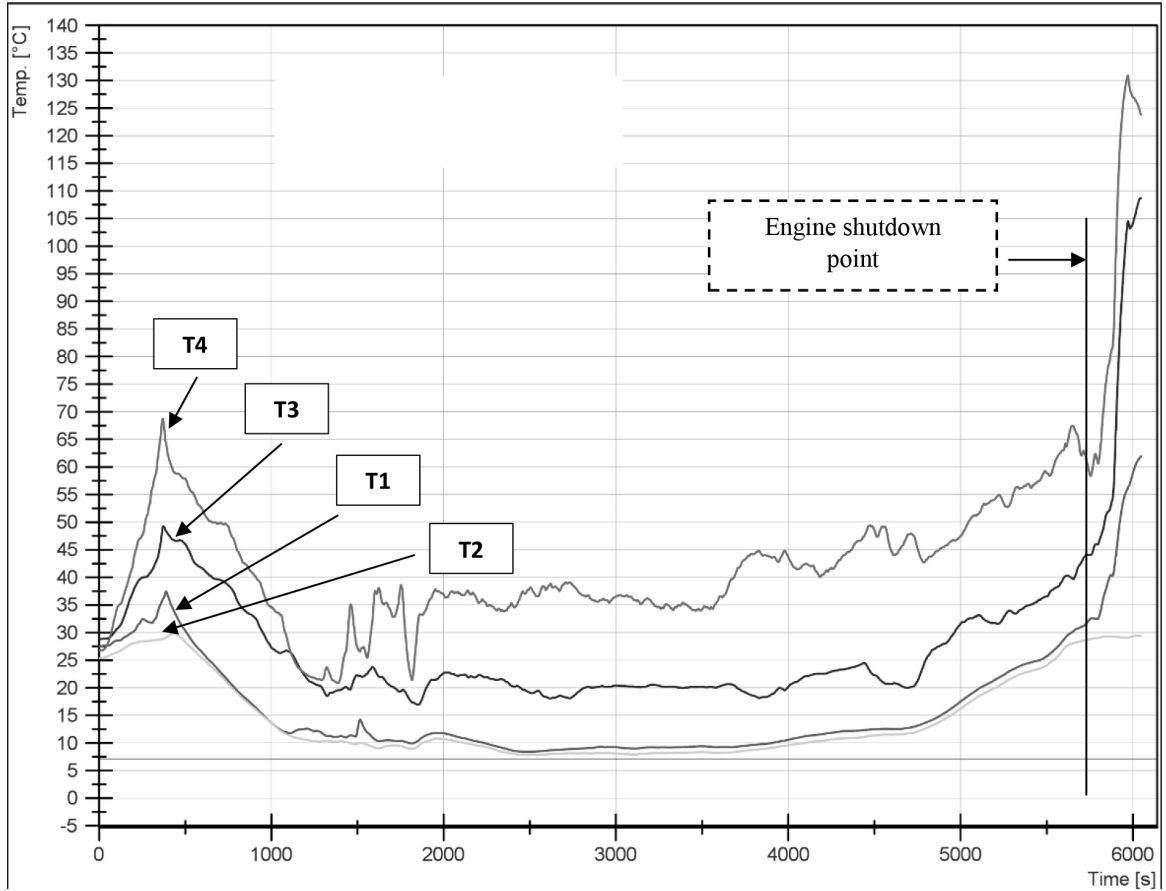

Fig. $7 . \mathrm{T} 1 \div \mathrm{T} 4$ temperatures recorded during the test flight. Ambient temperature at take-off and landing altitude was $31{ }^{\circ} \mathrm{C}$

\section{TEST RESULTS OVERVIEW}

The CS-23 requires the manufacturer to set the maximum outside air temperature (OAT) at altitude $0 \mathrm{~m}$ above mean sea level (AMSL) - the hot day conditions. It cannot be lower than $+38^{\circ} \mathrm{C}$ and is one of aircraft operation limits. For I-31T, the hot day temperature was set to $+40{ }^{\circ} \mathrm{C}$ and for this temperature, sufficient propulsion cooling must be provided. As the tests were conducted in conditions varying from the set hot day temperature (OAT was lower by almost $10{ }^{\circ} \mathrm{C}$ ), the recorded temperatures were corrected in accordance with requirement 23.1043 of CS-23.

The test shown that the highest (temporary - 1 minute duration) temperatures in the engine compartment are achieved straightaway after engine shutdown.

Table 1 shows recorded temperatures during hot day $\left(\mathrm{OAT}=+30^{\circ} \mathrm{C}\right)$ and corrected temperatures for the set limit temperature of $+40{ }^{\circ} \mathrm{C}$. 
Table 1. Recorded during tests and corrected temperatures

\begin{tabular}{|l|c|c|c|}
\hline $\begin{array}{c}\text { Location of temperature } \\
\text { measurement }\end{array}$ & $\begin{array}{c}\text { Maximum recorded } \\
\text { temperature }\left[{ }^{\circ} \mathrm{C}\right]\end{array}$ & $\begin{array}{c}\text { Limit temperature for } \\
\text { temporary and con- } \\
\text { tinuous operation }\left[{ }^{\circ} \mathrm{C}\right]\end{array}$ & $\begin{array}{c}\text { Corrected temperature } \\
\text { in accordance with } \\
\text { CS 23.1043(c) for } \\
\text { OAT }=+40{ }^{\circ} \mathrm{C} \text { at } 0 \mathrm{~m} \\
\text { AMSL }\left[{ }^{\circ} \mathrm{C}\right]\end{array}$ \\
\hline $\begin{array}{l}\text { External area of upper engine cowl } \\
\text { (aircraft symmetry plane close to } \\
\text { exhaust collectors) }\end{array}$ & $\begin{array}{c}+85 \\
\text { (maximum tempera- } \\
\text { ture recorded by the } \\
\text { strip indicator) }\end{array}$ & $+100 /+120$ \\
\hline $\begin{array}{c}\text { Ambient temperature ECU (T1) } \\
\left(+57^{\circ} \mathrm{C} \text { recorded by }\right. \\
\text { the indicator stuck } \\
\text { to the ECU) }\end{array}$ & $+70 /+70$ & +95 \\
\hline $\begin{array}{l}\text { Internal area of upper engine cowl } \\
\text { over gas generator (T2) }\end{array}$ & +83 & $+100 /+120$ & +70 \\
\hline $\begin{array}{l}\text { Internal area of upper engine cowl } \\
\text { over exhaust gases path (T3) }\end{array}$ & +93 & $+100 /+120$ & +103 \\
\hline $\begin{array}{l}\text { Internal area of upper engine cowl } \\
\text { over left exhaust collector (T4) }\end{array}$ & +74 & $+100 /+120$ & +84 \\
\hline
\end{tabular}

Comparison of the recorded temperatures with applicable limits yields that the requirements are met, i.e. the corrected temperatures in the engine compartment are lower than the temperatures set by the engine manufacturers for the corresponding engine components and cowling.

\section{CONCLUSIONS}

According to the CS-23 requirements, engine must be isolated from the airframe with firewalls. They must be designed in a way that prevents hazardous amount of fluids, gases or fire could not reach from the engine compartment to other airframe areas. This requirement may be challenging for design. The firewall and ventilation designs shown in Fig. 1 works correctly. The completed tests proved that temperatures in engine compartments are kept below the limits in the most detrimental conditions of operation in-flight and on the ground, including maximum operating altitudes and assumed maximum outside air temperature.

For engine compartment, the highest temperatures limiting operation occurred after engine shut down in the area of exhaust collectors. Temperature as high as $\mathrm{T} 4=131{ }^{\circ} \mathrm{C}$ was recorded, higher than curing temperature of applied epoxy resin $\left(120^{\circ} \mathrm{C}\right)$ and increase of composite in this area is necessary. It can be achieved by adding a protective layer of composite cured at temperature $180{ }^{\circ} \mathrm{C}$.

These features make the proposed solution suitable for Small Aircraft Transport (SAT) Aircraft Family Program [6], as well as for redesign of small aircraft to replace piston propulsion with turboprop one [7]. 


\section{BIBLIOGRAPHY}

[1] DECISION No. 2003/14/RM OF THE EXECUTIVE DIRECTOR OF THE AGENCY (EASA) of 14 November 2003 on certification specifications, including airworthiness codes and acceptable means of compliance for normal, utility, aerobatic and commuter category aeroplanes (CS-23).

[2] Balli O., "Advanced exergy analyses of an aircraft turboprop engine (TPE)", 2017, Energy, Vol. 124, pp. 599-612.

[3] Şöhret Yasin, Ekici Selcuk, Altuntaş Önder, Hepbasli Arif, Hikmet Karakoç T., "Exergy as a useful tool for the performance assessment of aircraft gas turbine engines: A key review", 2016, Progress in Aerospace Sciences, Vol. 83, pp. 57-69.

[4] Dziubiński A. "BE1 tractor nacelle, inlet, oil cooler and exhaust thermal analysis", 25 February 2013, Efficient Systems and Propulsion for Small Aircraft (ESPOSA), ESPOSA-D.6.2.-2.

[5] Stalewski W. and Żółtak J. "The preliminary design of the air-intake system and the nacelle in the small aircraft-engine integration process", 2014, Aircraft Engineering and Aerospace Technology: An International Journal, Vol. 86 Issue: 3, pp. 250-258, doi: 10.1108/AEAT-01-2013-0015.

[6] Piwek, K., Wiśniowski, W. (2016), "Small air transport aircraft entry requirements evoked by FlightPath 2050", Aircraft Engineering and Aerospace Technology, Vol. 88, Issue 2, pp. 341-347.

[7] Iwaniuk, A., Wiśniowski, W. and Żółtak, J. (2016), "Multi-Disciplinary Optimisation Approach for a Light Turboprop Aircraft-Engine Integration and Improvement", Aircraft Engineering and Aerospace Technology, Vol. 88 Issue 2, pp. 348-355.

\section{BADANIA NA ZIEMI I W LOCIE SKUTECZNOŚCI CHŁODZENIA PRZEDZIAŁU SILNIKA TURBOŚMIGŁOWEGO}

\section{Streszczenie}

Praca zawiera wybrane wyniki badań w locie zespołu napędowego samolotu I-31T, które uzyskano podczas realizacji europejskiego projektu badawczego ESPOSA (Efficient Systems and Propulsion for Small Aircraft). Samolot I-31T jako platforma badawcza był wyposażony w silnik turbośmigłowy typu TP100 o mocy startowej $180 \mathrm{~kW}$. W pracy przedstawiono wyniki prób na ziemi i w locie przeprowadzone pod kątem sprawdzenia prawidłowości chłodzenia przedziału silnika. Prezentowane badania prezentują przeprowadzone próby chłodzenia aby dowieść, że temperatury elementów zespołu napędowego utrzymywane są w zakresie ograniczeń, ustalonych dla tych elementów przez producenta silnika, w najbardziej niekorzystnych warunkach użytkowania na ziemi i w locie do maksymalnej wysokości lotu i w warunkach maksymalnej temperatury otaczającej atmosfery oraz po normalnym wyłączeniu silnika. Praca nie porusza tematu chłodzenia oleju silnika.

Słowa kluczowe: samolot lekki, badania w locie, zabudowa silnika turbośmigłowego, integracja silnika turbośmigłowego z płatowcem, chłodzenie przedziału silnika. 